\title{
Hubungan Kadar Hemoglobin dengan Daya Tahan Kardiovaskuler pada Pegawai Wanita RS Semen Padang
}

\author{
Nurfazlina $^{1}$, Afriwardi $^{2}$, Nur Afrainin Syah ${ }^{3}$
}

\begin{abstract}
Abstrak
Wanita rentan memiliki kadar hemoglobin dibawah normal (anemia) karena mengalami pengurangan volume darah yang dikeluarkan secara alamiah, seperti saat menstruasi. Penurunan kadar hemoglobin dapat berdampak pada penurunan daya tahan kardiovaskuler hingga berdampak pada produktivitas. Tujuan penelitian ini adalah mengetahui hubungan kadar hemoglobin terhadap daya tahan kardiovaskuler pada pegawai wanita RS Semen Padang. Jenis penelitian adalah analitik observasional dengan desain cross sectional study terhadap subjek sebanyak 85 orang. Data dikumpulkan dari hasil Medical Check Up (MCU) yang kemudian dianalisis melalui uji korelasi Spearman. Hasil penelitian ini mendapatkan 16,5\% pegawai wanita RS Semen Padang mengalami anemia. Sebanyak 3,5\% pegawai wanita RS Semen Padang memiliki daya tahan kardiovaskuler sangat baik, 17,6\% baik, 28,2\% sedang, 8,2\% kurang dan $42,4 \%$ kurang sekali. Hasil uji korelasi didapatkan nilai $r=+0,077$ dan nilai $P>0,05$. Kesimpulan penelitian ini adalah terdapat korelasi searah antara kadar hemoglobin terhadap daya tahan kardiovaskuler, namun kekuatan korelasi sangat lemah sehingga tidak terdapat hubungan bermakna antara kadar hemoglobin dengan daya tahan kardiovaskuler pada pegawai wanita RS Semen Padang.
\end{abstract}

Kata kunci: daya tahan kardiovaskuler, hemoglobin, wanita

\begin{abstract}
Women are more likely to have lower hemoglobin levels (anemia) due to menstruation. The decrease of hemoglobin levels will cause the decline of cardiovascular endurance. The objective of this study was to determine the correlation of hemoglobin levels and cardiovascular endurance in female employees of Semen Padang Hospital. This research was a observational analytic research using cross sectional design on 85 samples. Data was collected from Medical Check Up (MCU) record of female employees of Semen Padang Hospital and analyzed by Spearman correlation test. The results showed that $16,5 \%$ of samples were anemia. There were 3,5\% samples had high cardiovascular endurance, $17,6 \%$ good, $28,2 \%$ avarage, $8,2 \%$ low dan $42,4 \%$ poor. The results of correlation test (r) is $+0,007$ and the the significance value $(p)$ is $>0,05$. In conclution, the percentage of anemia in female employees of Semen Padang Hospital was low, but the majority of female employees of Semen Padang Hospital had low and poor cardiovascular endurance. The correlation between hemoglobin levels and cardiovascular endurance was positive. The strength of the correlation was very weak and there was no significant correlation between hemoglobin levels and cardiovascular endurance among female employees of Semen Padang Hospital.
\end{abstract}

Keywords: cardiovascular endurance, hemoglobin levels, women

Affiliasi penulis: 1. Prodi Profesi Dokter FK UNAND (Fakultas Kedokteran Universitas Andalas Padang), 2. Bagian Fisiologi FK UNAND, 3. Bagian Anatomi FK UNAND

Korespondensi: Nurfazlina, email : nrfzln@gmail.com. Telp: 085210053435

\section{PENDAHULUAN}

Daya tahan kardiovaskuler merupakan salah satu komponen kesegaran jasmani, selain kekuatan, daya tahan, dan kelenturan otot, komposisi tubuh, ketangkasan, kecepatan, keseimbangan, kecepatan reaksi dan koordinasi. ${ }^{1,2}$ Daya tahan merupakan komponen kesegaran jasmani terpenting, bahkan 
sering diartikan sama dengan kesegaran jasmani itu sendiri. $^{3,4}$ Seseorang yang memiliki daya tahan kardiovaskuler yang baik akan memiliki kapasitas kerja aerobik yang tinggi sehingga tingkat produktivitas meningkat. ${ }^{5}$ Penelitian NHANES USA terhadap masyarakat sipil mendapatkan prevalensi daya tahan kardiovaskuler yang rendah sebesar 21,2\% dengan prevalensi lebih banyak pada wanita. ${ }^{6}$ Hasil survey Depkes RI tahun 2002 pada PNS kantor dinas kesehatan dan pemerintah daerah provinsi di Sumatra Selatan, DKI Jakarta, Jawa Barat, dan Bali, mendapatkan prevalensi daya tahan kardiovaskuler rendah sebesar $73 \%{ }^{7}$ Daya tahan kardiovaskuler merupakan gabungan sistem jantung, pembuluh darah dan paru yang bekerjasama dalam mengambil oksigen secara maksimal dan menyalurkan ke jaringan aktif sehingga dapat digunakan pada proses metabolisme tubuh., ${ }^{4,8}$ Banyak faktor yang mempengaruhi daya tahan kardiovaskuler, diantaranya sel darah merah (hemoglobin). ${ }^{9}$ Penurunan kadar hemoglobin dapat berdampak pada penurunan daya tahan kardiovaskuler. $^{8}$ Wanita rentan dengan kejadian anemia (kadar hemoglobin dibawah normal) karena wanita mengalami pengurangan volume darah yang dikeluarkan secara alamiah, seperti saat menstruasi. ${ }^{10}$ Penelitian pada pegawai wanita di Nigeria Tenggara yang umumnya merupakan tenaga pendidik dan tenaga kesehatan mendapatkan rata-rata pegawai dengan level junior dan intermediet mengalami anemia. ${ }^{11}$ Berdasarkan observasi pendahuluan dari data Medical Check Up (MCU) pegawai wanita RS Semen Padang tahun 2013, didapatkan \pm 15,5\% pegawai mengalami anemia. Berdasarkan uraian diatas, perlu diteliti apakah terdapat hubungan kadar hemoglobin terhadap daya tahan kardiovaskuler pada pegawai wanita RS Semen Padang.

\section{METODE}

Penelitian ini adalah analitik observasional dengan desain cross sectional study. Populasi penelitian adalah seluruh pegawai wanita RS Semen Padang yang melakukan Medical Check Up (MCU) pada tahun 2013.

Sampel penelitian ditentukan menggunakan teknik total sampling yaitu bagian populasi yang telah memenuhi kriteria inklusi dan eksklusi diambil sebagai sampel. Kriteria inklusi adalah mempunyai data MCU tahun 2013 yang yang lengkap sesuai dengan data yang dibutuhkan dalam penelitian (identitas lengkap meliputi NIP pegawai, unit kerja, umur, hasil Schneider Test (Daya Tahan Kardiovaskuler) dan kadar hemoglobin. Kriteria eksklusi adalah memiliki riwayat penyakit pada sistem kardiovaskuler, pada sistem pernafasan, penyakit metabolik, memiliki berat badan tidak ideal (IMT tidak normal), mempunyai kebiasaan merokok dan mempunyai kebiasaan olahraga yang baik. Subjek berjumlah 85 orang. Variabel dependen adalah daya tahan kardiovaskuler dan independen adalah kadar hemoglobin. Pengolahan data adalah pemeriksaan kelengkapan dan kejelasan data, pemberian kode pada setiap data variabel, memasukkan data dalam program komputer serta pemeriksaan kembali untuk memastikan bahwa data tersebut telah bersih dari kesalahan. Analisis data terdiri dari analisis univariat dan bivariat. Pada analisis bivariat dilakukan dengan menggunakan uji korelasi Pearson jika distribusi data normal, tetapi jika tidak normal dilakukan uji korelasi Spearman.

\section{HASIL}

\section{Karakteristik Responden}

Tabel 1. Karakteristik subjek penelitian menurut umur

\begin{tabular}{clcc}
\hline & Umur & $\mathbf{n}$ & $\%$ \\
\hline- & $21-30$ tahun & 71 & 83,5 \\
- & $31-40$ tahun & 11 & 12,9 \\
- & $41-50$ tahun & 3 & 3,5 \\
\hline Jumlah & & $\mathbf{8 5}$ & $\mathbf{1 0 0}$
\end{tabular}

Berdasarkan Tabel 1 dapat diketahui bahwa pegawai wanita RS Semen Padang terbanyak adalah yang berumur 21-30 tahun.

Tabel 2. Karakteristik sampel berdasarkan unit kerja

\begin{tabular}{clcc}
\hline & Unit Kerja & N & $\%$ \\
\hline- & Pelayanan & 78 & 91,8 \\
- & Non pelayanan & 7 & 8,2 \\
\hline Jumlah & & $\mathbf{8 5}$ & $\mathbf{1 0 0}$
\end{tabular}

Karakteristik sampel berdasarkan unit kerja, dikategorikan dalam dua unit kerja yaitu pelayanan dan non pelayanan. Pelayanan meliputi ICU, OK, UGD/IGD, Persalinan, IW, Labor, Rawatan, Gizi, MR, 
Apotek, Satelit, KB, Admission dan Farmasi. Non pelayanan meliputi akutansi/keuangan, administrasi/ kesekretariatan, SDM, Humas, Pengadaan, Tata Usaha dan bagian penunjang pelayanan lainnya. Tabel 2 memperlihatkan bahwa pegawai wanita RS Semen Padang terbanyak adalah yang bekerja dalam kategori pelayanan yaitu sebanyak 78 orang $(91,8 \%)$.

\section{Hasil Analisis Univariat}

Tabel 3. Distribusi kategori hemoglobin pegawai wanita RS Semen Padang

\begin{tabular}{lll}
\hline Hemoglobin & $\mathbf{N}$ & $\%$ \\
\hline Anemia & 14 & 16,5 \\
Tidak Anemia & 71 & 83,5 \\
\hline Jumlah & $\mathbf{8 5}$ & $\mathbf{1 0 0}$
\end{tabular}

Pada Tabel 3 dapat dilihat bahwa 14 orang pegawai wanita RS Semen Padang (16,5\%) mengalami anemia dan 71 orang pegawai wanita RS Semen Padang (83,5\%) tidak mengalami anemia.

Tabel 4. Distribusi kategori daya tahan kardiovaskuler pegawai wanita RS Semen Padang

\begin{tabular}{lll}
\hline $\begin{array}{l}\text { Kategori Daya Tahan } \\
\text { Kardiovaskuler }\end{array}$ & $\mathbf{n}$ & $\%$ \\
\hline Sangat Baik & 3 & 3,5 \\
Baik & 15 & 17,6 \\
Sedang & 24 & 28,2 \\
Kurang & 7 & 8,2 \\
Kurang Sekali & 36 & 42,4 \\
\hline Jumlah & $\mathbf{8 5}$ & $\mathbf{1 0 0}$ \\
\hline
\end{tabular}

Berdasarkan Tabel 4 dapat dilihat bahwa tiga orang pegawai wanita RS Semen Padang (3,5\%) memiliki daya tahan kardiovaskuler sangat baik, 15 orang pegawai wanita RS Semen Padang (17,6\%) memiliki daya tahan kardiovaskuler baik, 24 orang pegawai wanita RS Semen Padang (28,2\%) memiliki daya tahan kardiovaskuler sedang, tujuh orang pegawai wanita $\mathrm{RS}$ Semen Padang (8,2\%) memiliki daya tahan kardiovaskuler kurang dan 36 orang pegawai wanita RS Semen Padang (42,4\%) memiliki daya tahan kardiovaskuler kurang sekali.

\section{Hasil Analisis Bivariat}

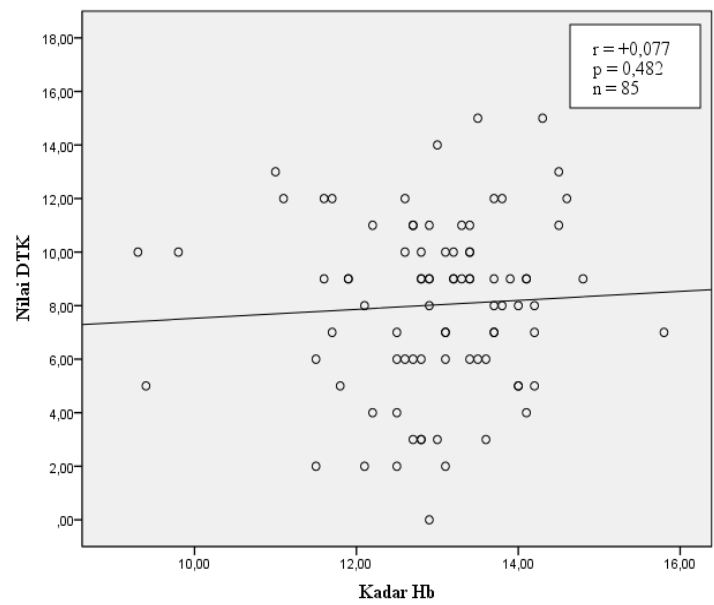

Gambar 1. Hubungan kadar hemoglobin dengan daya tahan kardiovaskuler

Hasil uji korelasi diperoleh nilai korelasi positif 0,077 yang menunjukkan bahwa arah korelasi searah (semakin besar nilai satu variabel semakin besar pula nilai variabel lainnya) dan kekuatan korelasi sangat lemah $(0,0 \mathrm{~s} / \mathrm{d}<0,2)$. Nilai $\mathrm{P}$ sebesar 0,482 menunjukkan bahwa tidak terdapat hubungan yang bermakna antara dua variabel yang diuji $(P>0,05)$.

\section{PEMBAHASAN}

\section{Kadar Hemoglobin}

Kadar hemoglobin dibawah normal (anemia) dapat terjadi akibat asupan zat besi yang kurang, gangguan absorpsi besi dan beberapa penyakit yang dapat menimbulkan anemia seperti malaria, infeksi cacing tambang, kehilangan darah saat operasi, penderita HIV/AIDS, kanker dan lain-lain. Faktor lain yang mempengaruhi anemia adalah fasilitas kesehatan, pertumbuhan, daya tahan tubuh, sosial ekonomi, pendidikan, merokok dan minum alkohol. Wanita sangat rentan dengan kejadian anemia karena mengalami pengurangan volume darah yang dikeluarkan secara alamiah, seperti saat menstruasi. Kadar hemoglobin yang normal diperoleh dengan memperhatikan dan mengoreksi faktor penyebab anemia diatas, seperti asupan zat besi yang cukup, tidak merokok, tidak minum alkohol dan aktivitas fisik yang cukup. ${ }^{10,12,13,14}$

Penelitian ini mendapatkan hanya sebagian kecil (16,5\%) pegawai wanita RS Semen Padang yang mengalami anemia. Hal ini sejalan dengan penelitian 
yang dilakukan oleh Schuepbach et al pada tahun 2011 terhadap pegawai rumah sakit di Switzerland dengan hasil sebagian besar pegawai wanita tidak anemia. $^{15}$ Hasil yang berbeda didapatkan oleh Olayiwola et al pada tahun 2012 di Nigeria Tenggara. Olayiwola et al menemukan kasus anemia sebesar $49,4 \%$ pada pegawai sipil wanita yang umumnya merupakan tenaga pendidik dan tenaga kesehatan. ${ }^{11}$

\section{Daya Tahan Kardiovaskuler}

Daya tahan kardiovaskuler merupakan kemampuan jantung, pembuluh darah dan paru untuk bekerjasama berfungsi secara optimal dalam keadaan istirahat dan kerja dalam mengambil oksigen secara maksimal dan menyalurkan ke jaringan aktif sehingga dapat digunakan pada proses metabolisme tubuh., ${ }^{4,8}$ Daya tahan kardiovaskuler dipengaruhi oleh umur, jenis kelamin, genetik, asupan gizi, aktivitas fisik, berat badan, kebiasaan merokok dan kebiasaan olahraga. Seorang yang memiliki daya tahan kardiovaskuler yang tinggi akan memiliki kapasitas kerja aerobik yang lebih besar karena orang ini umumnya akan memiliki pertukaran udara yang lebih ekonomis sewaktu kerja, kemampuan mencapai konsumsi oksigen maksimal yang lebih tinggi, kadar asam laktat darah yang lebih rendah sewaktu melakukan kerja tertentu dan lain-lain. Hal ini akan membuat orang tersebut berkonsentrasi lebih baik pada pekerjaan, memiliki kapasitas kerja yang lebih besar dan tidak cepat lelah sehingga tingkat produktivitasnya meningkat. ${ }^{7}$

Berdasarkan Tabel 4 dapat dilihat bahwa 3,5\% pegawai wanita RS Semen Padang memiliki daya tahan kardiovaskuler sangat baik, 17,6\% baik, 28,2\% sedang, 8,2\% kurang dan 42,4\% kurang sekali. Lebih dari separuh pegawai wanita RS Semen Padang memiliki daya tahan kardiovaskuler kurang dan kurang sekali. Hal ini sejalan dengan penelitian Iskandar pada tahun 2011 terhadap pegawai pria dan wanita di Rumah Sakit Al-Islam dengan hasil sebagian besar pegawai memiliki daya tahan kardiovaskuler kurang dan kurang sekali. ${ }^{16}$ Persentase daya tahan kardiovaskuler yang kurang dan kurang sekali $(50,6 \%)$ relatif lebih rendah dibandingkan penelitian yang dilakukan Skaal dan Pengpid (2011) terhadap pegawai rumah sakit di Afrika Selatan dengan $86 \%$ pegawai wanita memiliki daya tahan kardiovaskuler kurang dan kurang sekali. ${ }^{17}$

Persentase daya tahan kardiovaskuler kurang dan kurang sekali pada penelitian ini juga lebih rendah dibandingkan dengan penelitian yang dilakukan Hadi pada 2005 terhadap pegawai negeri sipil pada Dinas Kesehatan dan Dinas Pemerintah Daerah Tingkat I Provinsi Sumatra Selatan, DKI Jakarta, Jawa Barat, dan Bali. Sejumlah 69,7\% sampel perempuan memiliki daya tahan kardiovaskuler yang kurang dan kurang sekali. Hal ini kemungkinan terjadi karena pada populasi yang diteliti Hadi sebagian besar bekerja dibagian administrasi, sedangkan pada penelitian ini sebagian besar populasi bekerja dalam bentuk memberikan pelayanan sehingga lebih aktif. ${ }^{7}$

\section{Hubungan Kadar Hemoglobin dengan Daya Tahan Kardiovaskuler}

Pada Gambar 1 diperoleh nilai korelasi + (positif) 0,077 yang menunjukkan bahwa arah korelasi searah (semakin besar nilai satu variabel semakin besar pula nilai variabel lainnya. Arah korelasi pada hasil penelitian ini sesuai kepustakaan, bahwa hemoglobin berfungsi mensuplai oksigen keseluruh tubuh termasuk organ jantung dan paru dan hemoglobin dibawa oleh darah untuk mensuplai oksigen ke jaringan untuk metabolisme sehingga menghasilkan energi. Semakin tinggi kadar hemoglobin, semakin banyak oksigen yang dapat disuplai dan digunakan oleh organ dan jaringan sehingga daya tahan kardiovaskuler semakin meningkat. Hal ini sejalan dengan penelitian Yasrin pada tahun 2000 terhadap pegawai pemerintahan dan instansi di kota Padang yang menemukan bahwa semakin tinggi kadar hemoglobin, semakin tinggi nilai $\mathrm{VO}_{2}$ maks (daya tahan kardiovaskuler). ${ }^{18}$

Kekuatan korelasi antara kadar hemoglobin dan daya tahan kardiovaskuler pada penelitian ini sangat lemah $(0,0 \mathrm{~s} / \mathrm{d}<0,2)$ dan relatif lebih rendah dibandingkan dengan kekuatan korelasi yang didapatkan pada penelitian Yasrin dengan kekuatan korelasi sangat kuat $(r=9,10) .{ }^{18} \quad$ Nilai $P$ sebesar 0,482 menunjukkan bahwa tidak terdapat hubungan yang bermakna antara dua variabel yang diuji $(P>$ 0,05). Hal ini sejalan dengan penelitian Permaesih et 
al pada tahun 2000 bahwa tidak terdapat hubungan yang bermakna antara kadar hemoglobin dengan daya tahan kardiovaskuler. Pengaruh kadar hemoglobin terhadap daya tahan kardiovaskuler akan terlihat pada populasi yang memiliki prevalensi anemia yang besar. Pada penelitian ini didapatkan hanya sebagian kecil sampel yang mengalami anemia (16,5\%). Sedangkan, sebagian besar sampel memiliki daya tahan kardiovaskuler rendah. Hal ini menyebabkan kadar hemoglobin tidak berpengaruh secara nyata terhadap daya tahan kardiovaskuler. ${ }^{8}$

Keterbatasan penelitian ini adalah tidak dilakukan homogenitas sampel dari segi faktor aktivitas fisik, asupan gizi dan genetik sehingga dapat menjadi perancu dalam penelitian ini. Data penelitian hanya dari hasil Medical Check Up (MCU) tanpa melakukan pemeriksaan untuk menilai faktor genetik dan tidak menggunakan kuisioner untuk menilai aktivitas fisik dan asupan gizi sehingga tidak dapat ditentukan karakteristik sampel dari segi genetik, aktivitas fisik dan asupan gizi. Beberapa hal yang mungkin terjadi :

- Faktor genetik dari segi ukuran, struktur, dan fungsi jantung, serta proporsi serat otot skeletal yang buruk dapat menyebabkan daya tahan kardiovaskuler rendah.

- Aktivitas fisik yang rendah dapat menyebabkan daya tahan kardiovaskuler rendah.

- Asupan gizi yang rendah dapat menyebabkan daya tahan kardiovaskuler rendah.

Homogenitas sampel dari segi kebiasaan olahraga kemungkinan dapat mempengaruhi hasil penelitian ini. Penelitian ini menemukan sebagian besar sampel tidak memiliki kebiasaan olahraga yang baik sehingga peneliti menghomogenkan sampel dengan memilih sampel yang tidak memiliki kebiasaan olahraga yang baik dan mengeksklusi sampel dengan kebiasaan olahraga baik. Hal ini mungkin dapat menyebabkan sebagian besar sampel memiliki daya tahan kardiovaskuler rendah karena secara teori kebiasaan olahraga yang tidak baik dapat menyebabkan daya tahan kardiovaskuler rendah.

\section{KESIMPULAN}

Tidak terdapat hubungan bermakna antara kadar hemoglobin dengan daya tahan kardiovaskuler.

\section{DAFTAR PUSTAKA}

1. Rink JE, Hall TJ, Williams LH. Schoolwide physical activity, a comprehensive guide to desighning and conducting programs. United State of America: Human Kinetics; 2010.

2. US Department of Health and Human Service. Physical activity for everyone: glossary of terms; 2011 (diunduh 24 Januari 2014). Tersedia dari: URL: HYPERLINK http://www.cdc.gov/physical activity/everyone/glossary

3. Depkes RI. Buku skrining kesehatan olahraga: pengetahuan praktis tentang kesegaran jasmani. Jakarta; 1985.

4. Depkes RI. Panduan kesehatan olahraga bagi petugas kesehatan. Jakarta; 2002. hlm.12-14.

5. Wattles MG, Harris C. The Relationship between fitness levels and employee's perceived productivity, job satisfaction, and absenteeism. Journal of Exercise Physiology. 2003;6(1):24-32.

6. Agarwal S. Red cell distribution width, inflammatory markers and cardiorespiratory fitness: results from the national health and nutrition examination survey. Indian Heart Journal. 2012; 64:380-7.

7. Hadi HS. Daya tahan jantung paru dan faktor yang berhubungan pada pegawai negeri sipil umur 30 50 tahun di empat provinsi (Dinas Kesehatan dan Pemerintahan Daerah Tingkat I Sumatera Selatan, DKI Jakarta, Jawa Barat, dan Bali) (tesis). Jakarta: Fakultas Kedokteran Universitas Indonesia; 2005 (diunduh 30 Maret 2014). Tersedia dari: URL: HYPERLINK http://eprints.lib.ui.ac.id/11022/1/790 65\%2DT13622\%2DDaya\%20tahan\%2DTOC.pdf

8. Permaesih D, Kusdinar HE, Ivonne IM, Dangsina M, Hendro R. Faktor-faktor yang mempengaruhi ketahanan kardiovaskuler pada pria dewasa. Buletin Penelitian Kesehatan. 2000; 27(2):231-8.

9. Uliyandri A. Pengaruh latihan fisik terprogram terhadap perubahan nilai konsumsi oksigen 
maksimal $\left(\mathrm{VO}_{2} \max \right)$ pada siswi sekolah bola voli tugu muda Semarang usia 11-13 tahun (skripsi). Semarang: Fakultas Kedokteran Universitas Diponegoro; 2009 (diunduh 30 Maret 2014). Tersedia dari: URL: HYPERLINK http://eprint. undip.ac.id/8090/1/Adhikarma Uliyandari.Pdf

10. Wulandari. Waspadai anemia; 2008 (diunduh 30 Maret 2014). Tersedia dari: URL: HYPERLINK http://cybermed.cbn.net.id/cbprtl/cybermed/detail.a spx? $x=$ Health+Woman $\& y=$ cybermed $|0| 0|14| 838$.

11. Olayiwola I, Tijani A, Oguntona T, Oguntona C, Omisakin F. Female civil servant micronutrient status hematocrit level and health implication in South West Nigeria. International Journal of Health and Nutrition. 2012;3(2):6-11.

12. ILSI Europe. Healthy, lifestyle: nutrition and physical activity. ILSI Press; 2000.

13. Sadikin M. Biokimia darah. Jakarta: Widya Medika; 2002.

14. WHO. Haemoglobin concentration for the diagnosis of anaemia and assessment of severity. 2011 (diunduh 24 Januari 2012). Tersedia dari:
URL: HYPERLINK http://www.who.int/vmnis/ indicators/haemoglobin.pdf.

15. Schuepbach RA, Bestmann L, Bechir M, Fehr J, Bachli EB. High prevalence of iron defeciency among educated hospital employees in Switzerland. International Journal of Biomedical Science. 2011;7(2):150-7.

16. Iskandar F. Hubungan kebugaran jasmani dengan tingkat kinerja karyawan di rumah sakit Al-Islam Bandung; 2011 (diunduh 12 Juli 2014). Tersedia dari: URL: HYPERLINK http://pkr-ikor.upi.edu/?file =artikel\&mode=lengkap \&id=158

17. Skaal L, Pengpid S. Physical Activity, Fitnees level and health problems of healthcare worker in South Africa: the transtheoretical model as an explanatory framework. African Journal for Physical, Health Education, Recreation and Dance (AJPHERD). 2011;17(4):612-23.

18. Yasrin $\mathrm{Y}$. Correlation between hemoglobin and maximum $\mathrm{O}_{2}$ volume in civil servant in Padang. Majalah Kedokteran Andalas. 2000;24(1):16-9. 